\title{
Relations Among L2 Learning Motivation, Language Learning Anxiety, Self-efficacy and Family Influence: A Structual Equation Model
}

\author{
Huei-Ju Shih ${ }^{1} \&$ Shan-mao Chang ${ }^{1}$ \\ ${ }^{1}$ The Department of English, National ChangHua University of Education, Changhua, Taiwan, China \\ Correspondence: Huei-Ju Shih, The Department of English, National ChangHua University of Education, \\ Changhua, Taiwan, China. Tel: 886-935-580-868. E-mail: beckeystone@gmail.com
}

Received: September 17, 2018

Accepted: October 24, 2018 Online Published: October 26, 2018

doi: $10.5539 /$ elt.v11n11p148

URL: http://doi.org/10.5539/elt.v11n11p148

\begin{abstract}
The L2 Motivational Self System (L2MSS) has been widely researched and used to explain L2 learners' motivational behaviors. However, important factors such as language learning anxiety, self-efficay and possible family influence need to be scrutizized in relation to L2MSS in order to expand our understanding of the second language learning process. This study used a structural eauation modeling approach to test a hypothesized model that contained the L2 Motivational Self System, family influence, L2 learning anxiety, and self-efficacy as the latent variables in a context of foreign language learning. A total of 473 Taiwanese high school students participated in the study. With Amos version 22.0, the current study analyzed the proposed model. The results assured the validity of the hyposized model among these students. This model revealed that family influence played a significant role in affecting learners' future self guides. Self guides served as a good predictor for the L2 learners' self-efficacy. In addition, the ought-to L2 self contributed to a higher level of anxiety while the ideal L2 self and L2 learning experience both lowered the level of English learning anxiety.
\end{abstract}

Keywords: L2 Motivational self system, second language learning anxiety, self-efficacy, English as a foreign language

\section{Introduction}

\subsection{Background of the Problem}

Motivation is one of the most complicated concepts and investigating its nature has often resulted in contradictory findings in second language acquisition (SLA) research. Motivation can be regarded as a set of impetus that drive or even determine one's behavior (Nevid, 2013). Second language motivation research can date back to the late 1950s, when Gardner and his colleagues produced their works. These works engendered Gardner's (1985) influential socio-educational model. This model conceptualizes that motivation is composed of three dimensions: motivational strength, aspiration to undestand the target language (TL), and perspectives toward the TL. Although substantial research concerning this topic has contributed to its completeness, most related concepts centered around Gardner's integrative motive (Gardner, 1985; Gardner \& Lambert, 1972), particularly until the cognitive movement in the 1990s.

Exploration of learners' motivation facilitates investigating the factors that drive learners to dedicate their efforts to second language (L2) achievement, and offers deeper perspectives into how second language learners connect to their present social surroundings and even the globe (Ryan, 2008). L2 Motivational Self System (L2MSS) from Dörnyei $(2005,2009)$ provides researchers with the opportunity to investigate this elusive topic. The framework has been applied to various areas; such as being applied across different cultural and linguistic zones, for instance, Csizér and Kormos (2009), Ryan (2009), and Taguchi et al. (2009), in the globalization as well as conceptualizations of identity (Lamb, 2009; Yashima, 2009), and in other main paradigms in SLA (Kim, 2009). However, scarcely has research been conducted on integrating various aspects of second language learning motivation with the emotional variables such as anxiety, or personal belief, such as self-efficacy in a suggested framework. Anxiety is generally considered to impede the process of learning (Arnold \& Brown, 1999). Horwitz, Horwitz, and Cope (1986) even claimed that in learning a language, second language anxiety is a major obstacle. Self-efficacy, individuals' beliefs that they can overcome challenging tasks, is a dominant factor in 
language-learning achievement. By applying structural equation modeling (SEM), the aim of the present study was to make evaluatations on a motivational paradigm subsuming hypothetical paths between (a) the L2 Motivational Self System, (b) Second language learning anxiety, and (c) learners' self-efficacy in learning English. The factor influencing the L2MSS was also confirmed in the present study.

\subsection{Gardner's Integrative Orientation and Dörnyei's L2 Motivational Self System}

Motivation is one of the most-researched affective factors because it has been considered to have a robust relationship with successful language learning. Its definition is the inner force or emotion moving a person to engage in a certain action. Research on L2 motivation in the 1970s was dominated by Gardner and his research partners (Gardner \& Lambert, 1972). Their socio-educational model conceptualizes motivation to be composed of three components, namely motivational strength, aspiration to acquire the target language (TL), and insights toward the TL. Gardner categorized language learning motivation into two dichotomies, integrative and instrumental ones, which are often discussed in the research literature. Integrativeness is for the language learners to integrate themselves with the TL culture. Instrumentality means the language learners use the language as a tool to achieve their goals, such as finding a job. The concept of integrativeness/integrative motive was advocated as a prominent theory of L2 learning motivation and was considered to best predict the results of L2 learning (Gardner, 1985). Integrativeness and perspectives toward the learning context are viewed as crucial antecedents of motivation. Integrativeness involves incorporating inner thought toward the TL society and willing to learning foreign languages, whereas inner thought toward the learning environment entail incorporating evaluation in both the instructors and the course.

Gardner's research does not adequately explain the phonomenon of learning a second language. Gardner's research was conducted in Canada, an ESL context where learners have direct access to the TL-English. Integrativeness may not explain learners' inner thoughts in EFL contexts where learners have no direct access to the L2. Criticisms of Gardner's theory suggest that integrativeness could not capture the new conceptualizations of social identity. Examples of criticisms focus on the drawbacks of the theory, such as its inapplicability to educational contexts (Crooks \& Schmidt, 1991), inability of integrating cognitive concepts with language learning motivation (Dörnyei, 1994; Oxford \& Shearin, 1994), and failure of the adjustment to new identity (McNamara, 1997; Norton, 1995). The study of motivation has thus turned to a process-oriented and cognitive-situated approach. Such research has typically explored major motivation theories from the perspective of psychology, such as the theories of self-worth, self-efficacy, attribution, and expectancy-value. The cognitive-situated period of second language motivation studies shifted the attention to classroom-specific aspects of motivation and produced an effective basis for implications directly related to classroom practice (Dörnyei, 2007).

The validity of the integrative motivation has been challenged in the past decades. Dörnyei investigated 13,000 Hungarian young learners longitudinally. On the basis of the investigation findings, Dörnyei questioned the role of the integrative orientation regarding language learners' motivation (Dörnyei et al., 2006). He suggested that the strength of integrative motive is diminished in the foreign language context. Based on patterns from both theories, Higgins' (1987) self-discrepancy theory, namely ought selves, together with Markus and Nurius' (1986) possible selves, as well as L2 motivational studies (e.g., Noels, 2003; Ushioda, 2001) combined with his own, Dörnyei $(2005,2009)$ has put forward the L2 Motivational Self System (L2MSS) subsuming three components: the ideal L2 self (ILS), ought-to L2 self (OLS), and L2 learning experience (LLE). The dimensions are described below.

(a) The ideal L2 self (ILS) conveys the wonderful portrait that an L2 user aspires to realize. According to Dönyei (2009), the root of the ideal self is inside the individual. It represents the combination of the individual's hopes. It is an image of a dreamed future self that incoporates every trait that the individual aspires to possess, and - in terms of a second language learner-TL competence is a trait that an L2 learner desires to own. Papi (2010) explained that the imaginative portrait of one's self to be a good second language user might become a strong impetus to diminish the divergences between the actual self and this ideal picture. Dörnyei et al. (2006) stressed that this L2 self is a viviacious and real picture with which one can witness, and sense. This indicates that the ultimate model of ideal self is a nativelike speaker of the TL. This concept correlates with Gardner's integrativeness. With a positive attitude, the ideal L2 self is identifying with the culture of the TL.

(b) The ought-to L2 self (OLS) means the properties that the individual thinks one should have with a view to meeting standards and to avoid potential negative results (Dönyei, 2009, p. 29). This dimension belongs to the L2-specific aspect. This motivator is based on perceived duties, obligations, or responsibilities. A research by Taguchi et al. (2009) revealed that the OLS is influenced by influences from family and the instrumentally 
prevention-focused aspects. But in terms of the overall effects on learners' motivated behavior, the ideal L2 self exert more influence. Furthermore, Csizér and Kormos (2009) found an interaction betwixt encouraging remarks from parents and the OLS. Although the OLS is not innate to the individual, it is gradually internalized as the individual's wonderful self (Dörnyei, 2009; Kim, 2009; Ryan, 2008).

(c) The L2 learning experience (LLE) relates to learners' perspectives to learning a second language and may be changed on different stiuations, such as the current learning context and personal past involvement in the curriculum, teaching materials, L2 instructor, and peers. As Dörnyei (2009) described, for some L2 learners, the wonderful involvement with the real-life learning procedures resulted in the initial motivation. Therefore, this experience is firmly linked to the actional phase in Dörnyei and Ottó's (1998) process-oriented paradigm, and intrinsic categories (Noel, 2003; Ushioda, 2001).

Many researchers have attempted to develop the system into an intact construct by integrating other variables such as anxiety (Papi, 2010), self-efficacy (Kormos et al., 2011; Ueki \& Takeuchi, 2012), achievement (Moskovsky et al., 2016), learners' learning style (Al-Shehri, 2009; Kim, 2011), and willingness to communicate (Munezane, 2015). Despite extensive exploration of the L2 MSS, no definite framework has been established because of the diversity and volatility of the variables. In the EFL context, the application of L2MSS is still very scarce. Hence the present study aims to establish a framework of the L2MSS together with the personal belief factor, self-efficacy and affective factor, L2 anxiety to be applied in the EFL context.

\subsection{L2 Learning Anxiety and Motivation}

Anxiety, by Spielberger (1983) is defined as the individual emotion of apprehension related to consciousness of the autonomic nervous system. Spielberger, Anton, and Bedell (1976) categorized anxiety as either trait anxiety, innate in nature or state anxiety, triggered by environment. Trait anxiety refers to a stable feeling to get anxious all the time. State anxiety is a transit feeling, which may change over time and the intensity varies. Scovel (1978) proposed two dichotomies: facilitating versus debilitating anxiety. Under this framework, debilitating anxiety negatively affects performance, whereas facilitating anxiety tends to strengthen learners' performance. Dörnyei (2005) also proposed two dimensions for comprehending anxiety, in addition to state versus trait anxiety: beneficial or facilitating anxiety and inhibitory or debilitating anxiety. The beneficial versus facilitating category represents the extent to which positively or negatively anxiety affects learning. By contrast, the trait versus state anxiety category concerns the sustaining property of anxiety, that is, continuous or momentary feeling of worry.

As for L2 anxiety, previous research specifically refers to the feeling of tension and apprehension related to L2 contexts, in the face of listening, learning, and speaking (MacIntyre \& Gardner, 1994). Language learning anxiety, by MacIntyre and Gardner's (1991b) classification, is a trait anxiety recurring in contexts of language learning. Foreign language classroom anxiety (FLCA), or foreign language learning anxiety (FLA), is situation-specific anxiety (E. K. Horwitz, M. B. Horwitz, \& Cope, 1991; MacIntyre, 1999; MacIntyre \& Gardner, 1991a, 1991b), of which the intensity may flunctuate across different situations. L2 anxiety has been demonstrated to hinder the achievement in learning a foreign language and to negatively affects the process in language learning (Horwitz \& Young, 1991). Results from most studies have proved that the negative associations with L2 anxiety and a variety of L2 achievement scales (Aida, 1994; Coulombe, 2000; Gardner, 2005; Saito \& Samimy, 1996), language learning motivation (Csizér \& Dörnyei, 2005; Dörnyei, 2005; Dörnyei, Csizér, \& Németh, 2006; MacIntyre, 2002), language proficiency (Horwitz, 1995; MacIntyre \& Gardner, 1991a, 1991b; MacIntyre, Noels, \& Clément,1997), self-efficacy (Mills, Pajares, \& Herron, 2007), and self-confidence (Clément, Gardner, \& Smythe, 1980).

In terms of the relationship concerning the L2MSS and L2 anxiety, there is scarce research. Papi (2010) reported that the ILS was negatively, whereas the OLS was positively related to L2 anxiety. In line with the aforementioned research, Ueki and Takeuchi (2013) found the similar interaction of the self-guides between the L2MSS and L2 anxiety. Speaking of the measurement tool for anxiety in language learning, the Foreign Language Classroom Anxiety Scale (FLCAS) developed by Horwitz (1991) is most utilized. Critics, however, have claimed that this componential structure has been unable to be fully confirmed (Aida, 1994; Cheng, Horwitz, \& Schallert, 1999; Tóth, 2008). In consideration of this fact, the present study adopted the tool in Papi (2010) to measure L2 anxiety.

\subsection{Social Cognitive Theory by Bandura and Self-efficacy}

Self-efficacy, by Bandura's (1997) definition, is the faith in one's capacity to manage and to carry out the procedures of actions needed to generate given attainment), and it in turn determines the steps an individual may take. Self-efficacy has been extensively researched since the 1970s (Bandura, 1997, Klassen, Krawchuk, \& Rajani, 2008). Self-efficacy, according to Bandura (1989, 1993), can influence personal performance greater 
than capacity. In the case of pursuing foreign language knowledge, those with intensified self-efficacy participate more readily, and sustain for longer periods, and they thus attain a higher performance rank.

Four types of sources, identified by Bandura (1977), help to appraise self-efficacy. They are vicarious experiences, verbal persuasions, performance accomplishments, and physiological states. Vicarious experiences refer to how efficacious people who have good models to follow raise their self-efficacy through social comparisons. Verbal persuasions indicate that persuasive encouraging remarks from others can also elevate self-efficacy, and so can positive feedback. Performance accomplishments, relied on personal proficient experiences, are especially powerful. Success enhances mastery expectations, whereas consecutive failures weaken them. Physiological states (e.g., heart rate and sweating) indicate an increase in or deterioration of self-efficacy. Manifestiations signaling anxiety might reveal that an individual's deficiency of skills. Studies have determined that self-efficacy is able to predicts learners' academic performance (Bong, 2002; Pajares, 1996). Some studies have discussed self-efficacy in association with learners' achievement (Asakereh \& Dehghannezhad, 2015; Johnson, 2017; Khodadad \& Kuar, 2016; Lee, Bong, \& Kim, 2014), L2 anxiety (Sparks \& Patton, 2013), self-regulatory strategy (Cohen, 2012; Nelson \& Manset-Williamson, 2006), and goal setting (Akama, 2006; Brusso \& Orvis, 2013; Jawahar \& Elango, 2001). Apart from Ueki \& Takeuchi (2013), few studies have explored the relationships between the L2MSS and self-efficacy. The related studies are relatively rare in the EFL context.

\subsection{Purpose of the Study and the Hypothesized Model}

The purpose of the study is to investigate the relations among L2MSS, self-efficacy, anxiety and family influence by examing a hypothesized model that contain these four variables using a structural equation modeling approach. For the purpose of the study, a initial hypothesized model was constructed on the basis of a review of previous studies. The model is composed of six variables. The hypothesized model is displayed in Figure 1.

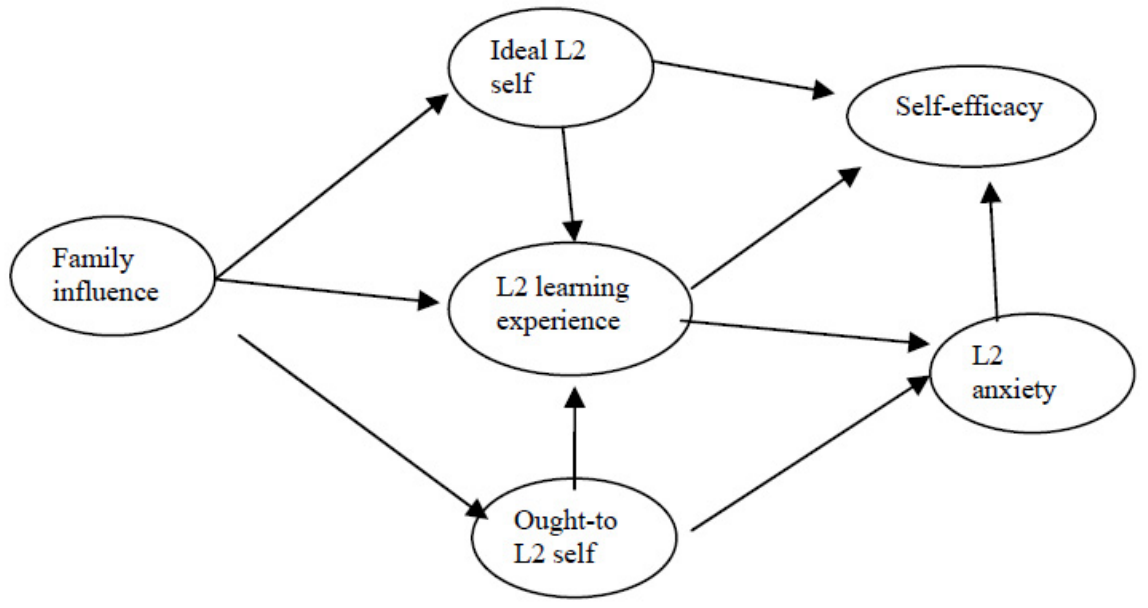

Figure 1. Hypothesized model

The causal relationships of the hypothetical model are revealed in single-headed arrows. The three paths from family influence leading to the three self-guides indicate that in an Asian sociocultural context, family influence plays a significant role (Lockwood, Marshall, \& Sadler, 2005; Markus \& Kitayama, 1998). The three ingredients of the L2MSS here were assumed to be influenced by family. This assumption appeared in the study by Taguchi et al. (2009). Unlike what was in Taguchi et al. (2009) that only ought-to L2 self was affected by family influence, this study hypothesized that all the three components were under influence of the participants' family.

The two paths leading from the ILS and OLS to LLE were proved in Papi (2010). The three paths leading to self-efficacy from the ILS, LLE, and L2 anxiety were based on the findings of previous studies that learners' self-efficacy could be affected by learners' level of vicarious experiences, verbal persuasions, personal accomplishments, and physiological states. Verbal persuasions may result in anxiety, and physiological states may indicate the state of being anxious. Hence, the single-headed arrows illustrate the relationship among the 
latent variables.

The two paths leading to L2 anxiety from LLE and OLS were added under the assumption that negative learning experiences and the aspiration to meet others' anticipations and avoid potential negative results contribute to L2 anxiety. The path from English learning experience has been supported by plenty of research (e.g., Papi, 2010; Young, 1991). Furthermore, the path leading from the OLS has been confirmed by studies such as Higgins (1987) and Carver, Lawrence, and Scheier (1999).

\section{Method}

\subsection{Participants}

In this study, convenience sampling was employed for participant selection. The participants' age ranged from 15 to 19 (mean, 17.1) years. The English subject was a compulsory one. Their experience of learning with native English-speaking instructors was low and that the overseas experiences were also rare. The situation appropriately represented a classical foreign language context. Because convenience sampling was applied in this study, participants were selected from the same high school where the researcher worked. After the deletion of students with missing data and invalid answers to the questionnaires, 473 students completed the survey.

\subsection{Research Tool}

The instrument used in the present study is a questionnaire with 7-point Likert scale, ranging from 1 (not at all) to 7 (very much), inclusive of items concerning learners' attitudes, L2 motivation, language learning self-efficacy, family influence, and English learning anxiety. Following Papi (2010) and Taguchi et al. (2009), the question items was developed in the current study. The original questionnaire was in English. To avoid the possible confusion that may be engendered by the low English proficiency levels of some participants, the description of items were translated into Mandarin Chinese by the researcher. The Chinese version was evaluated by one teacher who taught Chinese literature and one teacher who taught English grammar. The pilot study was administered among 112 high school learners. Feedback from the pilot study was further employed as the reference for modification and applied to the formal study. Structural equation analysis were used to evaluate all the variables and items, and the reliability coefficients were calculated.

The questionnaire sought information on six variables: (a) The ILS (14 items), with some modifications, from Papi (2010) and Taguchi et al. (2009); (b) the OLS (11 items), also from Papi (2010) and Taguchi et al. (2009); (c) the LLE (6 items) from Papi (2010). The original items were formatted as questions, but in the present study, the items were transformed into statements for ease of reply. (d) self-efficacy (14 items) from Piniel and Cizér (2013), with some other items being added to the original version; (e) family influence (10 items) obtained from Taguchi et al. (2009), indicating the influence of the participants' family members; and (f) English learning anxiety (6 items) derived from Papi (2010), describing participants' anxiety when learning English.

\subsection{Procedures}

The researcher first contacted other English teachers in the same school and described the survey's purpose and its administration procedure. The participants completed the questionnaires in class, and answering the items took the respondents 20 minutes on average. The standard deviations, means, and Cronbach Alpha coefficients were revealed in Table 1.

Table 1. Results of cronbach alpha coefficients, means, and standard deviations of the variables

\begin{tabular}{|c|c|c|c|}
\hline Variable Scales & Item no. & $\alpha$ & Mean/std. deviation \\
\hline $\begin{array}{l}\text { English } \\
\text { experience }\end{array}$ & $8,41,57,67,74,83$ & .93 & $4.02 / 1.33$ \\
\hline Ideal L2 self & $6,15,19,24,28,32,45,62,70,77,86,94$ & .95 & $4.19 / 1.62$ \\
\hline Ought-to L2 self & $9,14,18,44,61,71,79,88,89,96,102$ & .88 & $4.23 / 1.32$ \\
\hline Family influence & $3,10,38,54,64,72,80,91,98,104$ & .92 & $4.23 / 1.49$ \\
\hline L2 anxiety & $2,42,58,63,78,85$ & .95 & $4.03 / 1.44$ \\
\hline Self-efficacy & $4,11,20,21,25,30,39,55,65,73,82,90,97,103$ & .87 & $4.03 / 1.48$ \\
\hline
\end{tabular}




\section{Results of the Analysis}

AMOS version 22.0 for Structural Equation Modeling (SEM) was used to evaluate the collected data. Parameter estimation was analyzed with the maximum likelihood method. CFA (confirmatory factor analysis) provides the results of validity and reliability of the hypothetical model and testifies whether the model is appropriate. All the latent variables, therefore, underwent CFA. The current study considered the following indices in the analysis: adjusted goodness-of-fit index (AGFI), the normal fit index (NFI), goodness-of-fit index (GFI), incremental fit index (IFI), comparative fit index (CFI), Tucker-Lewis index (TLI), relative fit index (RFI), root mean square error of approximation (RMESA), and critical number $(\mathrm{CN})$. Good fitness is assumed if the values exceed 0.90 on a scale of 0-1.0. An RMSEA value lower than or equal to 0.05 is considered good by convention (e.g., Schumacker \& Lomax, 2004). Figure 2 reveals the diagrammatic description of the ultimate pattern with standardized path coefficients.

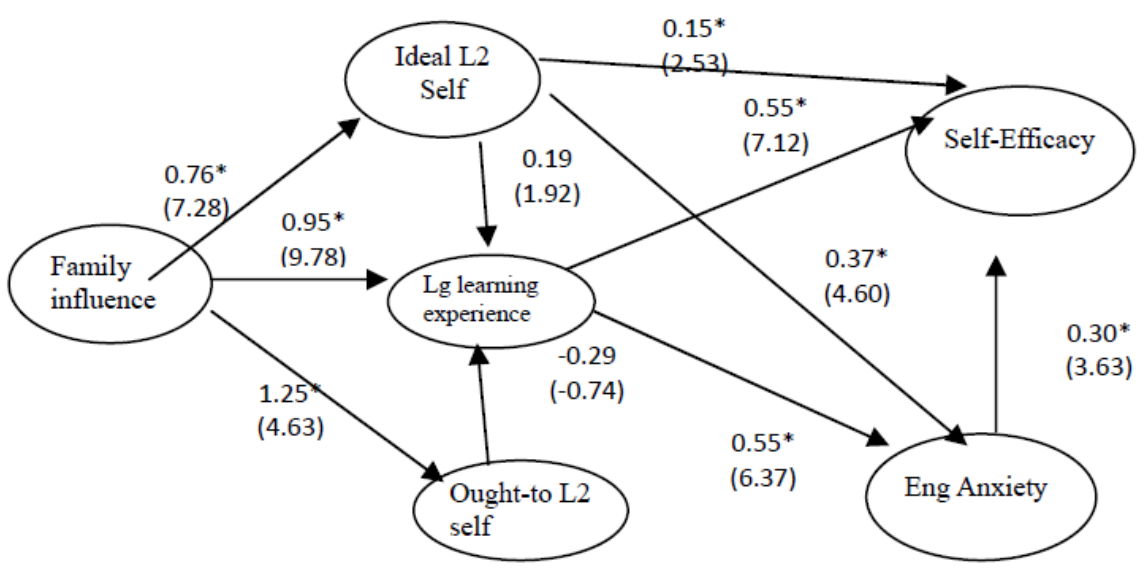

Figure 2. Hypothesized model with statistical results

In Figure 2, the numbers above the parentheses represent the path coefficient, and the numbers within the parentheses represent $t$ values. A $t$ value greater than 1.96 signifies that the result reaches the significance level. As illustrated in Figure 2, the values of path coefficients and residuals as well as the overall model fit indicators were appropriate. All but two (i.e., OLS->LLE and the ILS->LLE) of the hypothetical paths revealed significant level at least at the .05 one.

Table 2. Results of indices for the ultimate model

\begin{tabular}{llll}
\hline Names of Index & Criteria of Acceptance & Results & $\begin{array}{l}\text { Acceptable } \\
\text { Yes/No }\end{array}$ \\
\hline $\mathrm{X}^{2} / \mathrm{df}$ & & Yes \\
$\mathrm{NFI}$ & $<3$ & 1.749 & Yes \\
$\mathrm{RFI}$ & $>.90$ & .962 & Yes \\
$\mathrm{GFI}$ & $>.90$ & .958 & Yes \\
$\mathrm{AGFI}$ & $>.90$ & .912 & Yes \\
$\mathrm{IFI}$ & $>.90$ & .960 & Yes \\
TLI & $>.90$ & .978 & Yes \\
CFI & $>.90$ & .975 & Yes \\
RMESA & $>.90$ & .978 & Yes \\
CN & $<.05$ & .044 & Yes \\
\hline
\end{tabular}

Notes: NFI=normal fit index, RFI=relative fit index, GFI=goodness-of-fit index, AGFI=adjusted goodness-of-fit 
index, IFI=incremental fit index, TLI=Tucker-Lewis index, CFI=comparative fit index, RMESA=root mean square error of approximation, and $\mathrm{CN}=$ critical number.

According to Table 2, the value of $x^{2} / \mathrm{df}$ was 1.749 , which was acceptable because it was below 3 . Moreover, all the other indices in the model reached very satisfactory levels. Therefore, the final version of this model can be considered to be acceptable. The ILS as well as OLS did not contribute to the LLE in the present study. Therefore, the two single-headed arrows from the ILS and from the OLS to LLE should be deleted.

Ideal L2 self contributed to self-efficacy, with the corresponding path coefficient being 0.15 and $t$ value being 2.53, representing a significant level. The latent variable, English learning experience, affected self-efficacy, with the corresponding path coefficient being 0.55 and $t$ value being 7.12. In addition to self-efficacy, this variable positively affected English learning anxiety, with the path coefficient being 0.37 and $t$ value being 4.60. The OLS, contributed to English learning anxiety; the corresponding path coefficient was 0.55 and $t$ value was 6.37 , reaching the level of significance. Finally, English learning anxiety affected self-efficacy, as shown in the figure; the corresponding path coefficient was 0.30 and $t$ value was 3.63. Therefore, the model can be modified as follows.

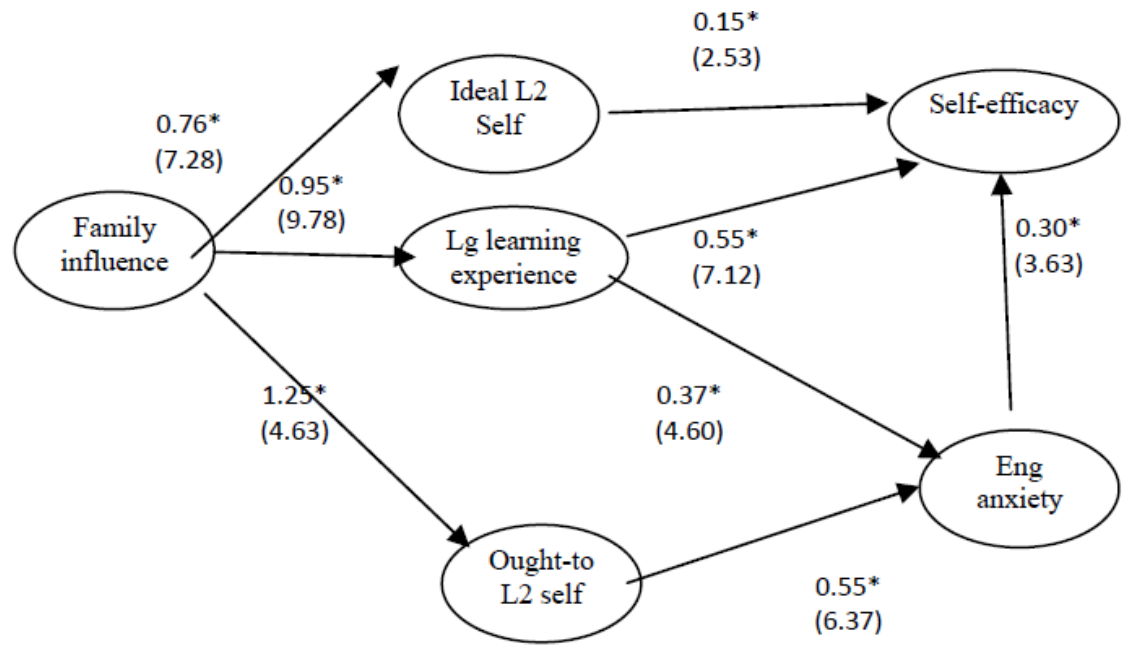

Figure 3. Final model

\section{Discussion}

The strong effect of family influence revealed that all three subcategories of the L2MSS were influenced by the participants' family members. The results somewhat diverged from previous studies (Csizér \& Kormos, 2009; Taguchi et al., 2009; Ueki \& Takeuchi, 2013). Taguchi et al. (2009) considered family influence to be a factor affecting the ought-to L2 self, and Ueki and Takeuchi (2013) considered other people's influence to be the factor contributing to ought-to L2 self. Parents' attitudes may be dominant in the learning processes of Taiwanese adolescent learners. Therefore, the role of family cannot be neglected. Although Ueki and Takeuchi (2013) indicated that others' influence was a predictor of the ought-to L2 self, the present study specifically revealed family influence to be the predictor of not only the OLS but also the ILS and LLE.

Family influence indirectly contributed to self-efficacy and English learning anxiety through two of the subcomponents of the L2MSS. Considering the findings of the present study, family influence could be the strongest predictor of self-efficacy and English learning anxiety. Apart from family influence, language learning experience was the second strongest pre-determinor of self-efficacy, and English learning anxiety was the third strongest.

With regards to the roles played by the components of the L2MSS, the English learning experience functions as a two-dimension factor. It not only influenced self-efficacy but also affected English learning anxiety, which in turn influenced self-efficacy. In contrast to ELE, the ILS predicted only self-efficacy, exerting the least influence in the model. The OLS influenced English learning anxiety and in turn influenced self-efficacy, being the second strongest predictor compared with the other components in the L2MSS. The findings are in contrast to those of 
Ueki and Takeuchi (2013), who reported that self-efficacy predicted the ILS and that the OLS yielded no predictive ability for self-efficacy. In contrast to the findings of previous studies (Papi, 2010; Ueki \& Takeuchi, 2013), the results in the current study indicate that all the components of the L2MSS function independently in this model.

Although some studies (e.g., Papi, 2010) have reported that an interactional path existed between the OLS and the ILS, the finding of the present study showed no relationship between the two self-guides. According to Markus and Nurius (1986), possible selves are generated under the interaction of the sociocultural and historical context. Therefore, the impact of family on Taiwanese high-school students was determined to be the largest. This means that the traditional family values dominate the learners' motivation and their future possible selves. According to the definition of the OLS by Dörnyei (2009), the source of the OLS is external to learners, because it deals with the obligations imposed by teachers, peers, parents, and other influential figures. The findings of the present study were in confirmation with Dörnyei's definition (2009).

Self-efficacy is generated from social cognitive learning theory. It is the belief that drive people to perform a particular task and fulfill it successfully (Bandura 1977, 1986, 1993, 1995, 1997). People with a strong efficacy belief face difficulty bravely and attempt to complete tasks successfully. In the present study, the ILS, LLE, and English learning anxiety directly, and the ought-to L2 self indirectly affected self-efficacy. The influence of the ILS on self-efficacy was stronger than that of the OLS. This evidently conforms to the general assumption that if the learning motive is more innate and self-internalized, the possibility that students achieve it is high (Noels et al., 1999). Moreover, the findings suggested that the ought-to L2 self enhanced level of anxiety, which was in line with those of previous studies (e.g., Papi, 2010), which might in turn affect L2 achievement. Among the influencing factors, English learning experience played a 2D role because it had a direct impact as well as an indirect impact on self-efficacy. The moderate role of English learning experience illustrated the fact that learners' self-efficacy was mediated by the learning attitude, the environment, task difficulty, family anticipation, and their past experience.

The impact of English learning experience on English learning anxiety was another noteworthy result in the current study. Similar to the results of previous research (Aida, 1994; Young, 1991), negative L2 experiences resulted in a high level of language learning anxiety, whereas positive experiences lowered the levels of anxiety associated with L2 learning.Regarding the sources of English learning anxiety, English learning experience as well as the OLS contributed to the level of English learning anxiety (Figure 3). Family influence indirectly increased the level of influence on English learning anxiety.

In the present study, L2 learning anxiety was found to contribute to self-efficacy belief. Self-efficacy belief is based on four principal aspects (Bandura, 1977, 1986, 1995): (a) Mastery experience: a person's success or failure results from the information the person has obtained. (b) Vicarious experience: the perception of one's success or failure by observing a similar model. (c) Social persuasion: a person's self-judgment is decided by the advice or approval from others. (d) Emotional arousal: mood deciding the strength of a person's self-efficacy. The L2 learning anxiety in the present study could be regarded as emotional arousal. The casual relationship between anxiety and self-efficacy was further identified in the study.

Concerning the language learning environment in Taiwan, the majority of people on this island shared similar historical background with China, and some people value Japanese culture a lot since its invasion of Japan in the early $20^{\text {th }}$ century. Under the two different veins of influence, Taiwanese young language learners possess very contradictory attitudes toward English. On the one hand, English is one of the prominent subjects required in college entrance examination. The importance of raising English proficiency cannot be over emphasized, which is the same as that in Japan and China (Taguchi et al., 2009). Young children are sent to the cram schools for English courses at an early age. Some youths even start to learn English at the very time they enter kindergarten. However, the heat wanes as they enter high school. On the other hand, owing to the prosperous economical status quo in Taiwan, the desire to work overseas or working in an international institute is not so high as to drive them to learn English. Hence English is less valued, as is in Japan (Taguchi et al, 2009). The pressure from examination makes English learning no longer interesting. For foreign language learners, to sustain L2 motivation is very crucial. According to the results in the current study, the factor "family influence" serves as a good predictor of the self-guides. In a country with Confucian heritage like Taiwan, the participants are deeply influenced by their family, including parents, siblings and relatives. Teachers are also viewed as their family members. Thus the family members together with the educators need to work hand in hand to offer the learners with positive learning experience through encouraging words or praise, lower the pressure from learning the target language, help illustrate the future ideal selves, and strengthen individual self-efficacy. These in turn will contribute to the improvement of learners' achievement. 


\section{Conclusion}

This study investigated the relations among the L2 learning motivation, language learning anxiety, self-efficacy and family influence. The study also reveals that in the participants' social context, family influence had a major role. Self-efficacy is generally thought to be closely related to one's achievements. To enhance a learner's self-efficacy, the enrichment of the ideal L2 self and positive language learning experience is considered necessary. Furthermore, the relief of L2 anxiety and avoidance of negative L2 learning experiences contribute to self-efficacy. With the insight into the participants' perceptions toward language learning gained from the present study, researchers can obtain a deeper realization of learners' inner world. In sum, the model constructed fit well for the present study. Family influence acts as a prominent predictor in affecting L2 Motivational Self Systems, and in turn influences the strength of L2 anxiety and individual's self-efficacy.

\section{Educational Implications And Directions for Future Research}

To assist learners build strong self-efficacy and lower L2 anxiety, family members should help learners build the ideal L2 self, offer a positive learning experience, and help them fulfill individual duties. Providing a motivating classroom environment is an urgent necessity. The current study concentrated on the effect of language learning motivational components (i.e., the ideal L2 self, ought-to L2 self, and language learning experience) on anxiety and self-efficacy. Further research that includes other latent variables, such as learners' strategies or intended effort, are suggested for further exploration of this topic.

\section{References}

Aida, Y. (1994). Examination of Horwitz, Horwitz, and Cope's construct of foreign language anxiety: the case of students of Japanese. Modern Language Journal, 78(2), 155-168. https://doi.org/10.1111/j.1540-4781. 1994.tb02026.x

Akama, K. (2006). Relations among self-efficacy, goal setting, and metacognitive experiences in problem-solving. Psychological Reports, 98(3), 895-907. https://doi.org/10.2466/pr0.98.3.895-907

Al-Shehri, A. S. (2009). Motivation and vision: The relation between the ideal L2 self, imagination and visual style. In Z. Dörnyei, \& E. Ushioda (Eds.), Motivation, Language Identity and the L2 Self (pp. 164-171). Bristol: Multilingual Matters, Clevedon. https://doi.org/10.21832/9781847691293-009

Arnold, J., \& Brown, H. D. (1999). A Map of the Terrain. In J. Arnold (Ed.), Affect in Language Learning (pp. 1-24). Cambridge: Cambridge University Press.

Asakereh, A., \& Dehghannezhad, M. (2015). Student satisfaction with EFL speaking classes: Relating speaking self-efficacy and skills achievement. Issues in Educational Research, 25(4), 345-363.

Bagozzi, R. P., \& Yi, Y. (1988). On the evaluation of structural equation models. Academic of Marketing Science, 16(1), 76-94. https://doi.org/10.1007/BF02723327

Bandura, A. (1977). Self-efficacy: Toward a unifying theory of behavioral change. Psychological Review, 84(2), 191-215. https://doi.org/10.1037/0033-295X.84.2.191

Bandura, A. (1986). Social foundations of thought and action: A social cognitive theory. Englewood Cliffs, NJ: Prentice Hall.

Bandura, A. (1989). Regulation of cognitive processes through perceived self-efficacy. Developmental Psychology, 25(5), 729-735. https://doi.org/10.1037/0012-1649.25.5.729

Bandura, A. (1993). Perceived self-efficacy in cognitive development and functioning. Educational Psychologist, 28(2), 117-148. https://doi.org/10.1207/s15326985ep2802_3

Bandura, A. (1995). Exercise of personal and collective efficacy in changing societies. In A. Bandura (Ed.), Self-efficacy in changing societies (pp. 1-45). New York, NY: Cambridge University Press. https://doi.org/10.1017/CBO9780511527692

Bandura, A. (1997). Self-efficacy: The Exercise of Control. New York: W. H. Freeman.

Bong, M. (2002). Predictive utility of subject-, task-, and problem specific self-efficacy judgments for immediate and delayed academic performances. Journal of Experimental Education, 70(2), 139-149. https://doi.org/10. 1080/00220970209599503

Brusso, R. C., \& Orvis, K. A. (2013). The impeding role of initial unrealistic goal-setting on videogame-based training performance: Identifying underpinning processes and a solution. Computers in Human Behavior, 29(4), 1686-1694. https://doi.org/10.1016/j.chb.2013.01.006 
Carver, C. S., Lawrence, J. W., \& Scheier, M. F. (1999). Self-discrepancies and affect: Incorporating the role of feared self. Personality and Social Psychology Bulletin, 25, 783-792. https://doi.org/10.1177/014616 7299025007002

Cheng, Y., Horwitz, E. K., \& Schallert, D. L. (1999). Language anxiety: Differentiating writing and speaking components. Language Learning, 49(3), 417-446. https://doi.org/10.1111/0023-8333.00095

Clément, R., Gardner, R. C., \& Smythe, P. C. (1980). Social and individual factors in second language acquisition. Canadian Journal of Behavioural Science, 12, 293-302. https://doi.org/10.1037/h0081081

Cohen, M. T. (2012). The importance of self-regulation for college student learning. College Student Journal, 46(4), 892-902.

Coulombe, D. (2000). Anxiety and beliefs of French-as-a-second-language learners at the university level. (Unpublished doctoral dissertation). University of Laval, Québec, Canada.

Crooks, G., \& Schmidt, R. W. (1991). Motivation: Re-opening the research agenda. Language Learning, 41(4), 469-512. https://doi.org/10.1111/j.1467-1770.1991.tb00690.x

Csizér, K., \& Dörnyei, Z. (2005). The internal structure of language learning motivation and its relationship with language choice and learning effort. Modern Language Journal, 89(1), 19-36. https://doi.org/10.1111/j.00 26-7902.2005.00263.x

Csizér, K., \& Kormos, J. (2009). Learning experiences, selves and motivated learning behavior: a comparative analysis of structural models for Hungarian secondary and university learners of English. In Z. Dörnyei, \& E. Ushioda (Eds.), Motivation, Language Identity and the L2 Self (pp. 98-119). Bristol: Multilingual Matters, Clevedon. https://doi.org/10.21832/9781847691293-006

Dörnyei, Z. (1994). Understanding second language motivation: on with the challenge! Modern Language Journal, 78(4), 515-523. https://doi.org/10.1111/j.1540-4781.1994.tb02071.x

Dörnyei, Z. (2003). Attitudes, orientations, and motivations in language learning: advances in theory, research, and applications. Language Learning, 51(1), 3-33. https://doi.org/10.1111/1467-9922.53222

Dörnyei, Z. (2005). The Psychology of the Language Learner: Individual Differences in Second Language Acquisition. Mahwah, NJ: Lawrence Erlbaum Associates. https://doi.org/10.1177/0261927X05281424

Dörnyei, Z. (2007). Research Methods in Applied Linguistics: Quantitative, Qualitative and Mixed Methodologies. Oxford: Oxford University Press.

Dörnyei, Z. (2008). New ways of motivating foreign language learners: generating vision. Links, 38 (Winter), 3-4.

Dörnyei, Z. (2009). The L2 motivational self system. In Z. Dörnyei, \& E. Ushioda (Eds.), Motivation, language identity and the L2 self (pp. 9-42). Bristol: Multilingual Matters, Clevedon.

Dörnyei, Z., \& Clément, R. (2001). Motivational characteristics of learning different target languages: results of a nationwide survey. In Z. Dörnyei, \& R. Schmidt (Eds.), Motivation and Second Language Acquisition (pp. 399-432). Honolulu, HI: University of Hawaii Press.

Dörnyei, Z., \& Csizér, K. (2002). Some dynamics of language attitudes and motivation: results of a longitudinal nationwide survey. Applied Linguistics, 23, 421-462. https://doi.org/10.1093/applin/23.4.421

Dörnyei, Z., \& Ottó, I. (1998). Motivation in action: A process model of L2 motivation. Working Papers in Applied Linguistics (Thames Valley University, London), 4, 43-69.

Dörnyei, Z., \& Ushioda, E. (2009). Motivation, Language Identity and the L2 Self. Bristol: Multilingual Matters, Clevedon. https://doi.org/10.21832/9781847691293

Dörnyei, Z., Csizér, K., \& Németh, N. (2006). Motivation, Language Attitudes and Globalisation: a Hungarian Perspective. Bristol: Multilingual Matters, Clevedon. https://doi.org/10.21832/9781853598876

Gardner, R. C. (1985). Social Psychology and Second Language Learning: The Role of Attitudes and Motivation. London: Edward Arnold.

Gardner, R. C. (2005). Integrative Motivation and Second Language Acquisition. Retrieved from http://publish.uwo.ca/wgardner/aaltalk5final.pdf 
Gardner, R. C., \& Lalonde, R. N. (1983). The socio-educational model of second language acquisition: An investigation using LISREL causal modeling. Journal of Language and Social Psychology, 2(1), 1-15. https://doi.org/10.1177/0261927X8300200101

Gardner, R. C., \& Lambert, W. E. (1972). Attitudes and Motivation in Second Language Learning. Rowley, MA: Newbury House.

Gardner, R. C., Tremblay, P. F., \& Masgoret, A. M. (1997). Toward a full model of second language learning: an empirical investigation. Modern Lnguage Journal, 81(3), 344-362. https://doi.org/10.1111/j.1540-4781. 1997.tb05495.x

Hashimoto, Y. (2002). Motivation and willingness to communicate as predictors of reported L2 use: the Japanese context. Second Language Studies, 20(2), 29-70.

Higgins, E. T. (1987). Self-discrepancy: a theory relating self and affect. Psychological Review, 94, $319-340$. https://doi.org/10.1037/0033-295X.94.3.319

Horwitz, E. K. (1991). Preliminary evidence for the reliability and validity of a foreign language anxiety scale. In E. K. Horwitz, \& D. J. Young (Eds.), Language anxiety: From theory and research to classroom implications (pp. 37-39). Englewood Cliffs, NJ: Prentice Hall.

Horwitz, E. K. (1995). Student affective reactions and the teaching and learning of foreign languages. International Journal of Educational Research, 23, 573-579. https://doi.org/10.1016/0883-0355 (96)80437-X

Horwitz, E. K., \& Young, D. J. (Eds.). (1991). Language anxiety: From theory and research to classroom implications. Englewood Cliffs, NJ: Prentice Hall.

Horwitz, E. K., Horwitz, M. B., \& Cope, J. (1986). Foreign language classroom anxiety. Modern Language Journal, 70(2), 125-132. https://doi.org/10.1111/j.1540-4781.1986.tb05256.x

Horwitz, E. K., Horwitz, M. B., \& Cope, J. A. (1991). Foreign language classroom anxiety. In E. K. Horwitz, \& D. J. Young (Eds.), Language anxiety: From theory and research to classroom implications (pp. 27-36). Englewood Cliffs, NJ: Prentice Hall.

Jawahar, I. M., \& Elango, B. (2001). The effect of attitudes, goal-setting and self-efficacy on end user performance. Journal of End User Computing, 13(2), 40-45. https://doi.org/10.4018/joeuc.2001040104

Johnson, I. (2017). Female faculty role models, self-efficacy and student achievement. College Student Journal, 51(1), 151-172.

Khodadad, M., \& Kuar, J. (2016). Causal relationships between integrative motivation, self-efficacy, strategy use and English language achievement. 3L: Southeast Asian Journal of English Language Studies, 22(3), 111-125.

Kim, T. Y. (2009). The sociocultural interface between ideal self and ought-to self: a case study of two Korean students' ESL motivation. In Z. Dörnyei, \& E. Ushioda (Eds.), Motivation, language identity and the L2 self (pp. 274-294). Bristol: Multilingual Matters, Clevedon.

Kim, T. Y. (2011). The L2 Motivational Self System and perceptual learning styles of Chinese, Japanese, Korean, and Swedish students. English Teaching, 66, 141-162.

Klassen, R. M., Krawchuk, L. L., \& Rajani, S. (2008). Academic procrastination of undergraduates: low self-efficacy to self-regulate predicts higher levels of procrastination. Contemporary Educational Psychology, 33(4), 915-931.

Kormos, J., Kiddle, T., \& Csizér, K. (2011). Systems of goals, attitudes, and self-related beliefs in second language learning motivation. Applied Linguistics, 32(5), 495-516.

Kunnan, A. J. (1998). An introduction to structural equation modelling for language assessment research. Language Testing, 15(3), 295-332.

Lamb, M. (2004). Integrative motivation in a globalizing world. System, 32(1), 3-19.

Lamb, M. (2009). Situating the L2 self: two Indonesian school learners of English. In Z. Dörnyei, \& E. Ushioda (Eds.), Motivation, language identity and the L2 self (pp. 229-247). Bristol: Multilingual Matters, Clevedon.

Lee, J., Bong, M., \& Kim, S. (2014). Interaction between task values and self-efficacy on maladaptive achievement strategy use. Educational Psychology, 34(5), 538-560. 
Lockwood, P., Marshall, T. C., \& Sadler, P. (2005). Promoting success or preventing failure: Cultural differences in motivation by positive and negative role models. Personality and Social Psychology Bulletin, 31(3), 379-392.

MacIntyre, P. D. (1994). Variables underlying willingness to communicate: a causal analysis. Communication Research Reports, 11, 135-142.

MacIntyre, P. D. (1999). Language anxiety: A review of the research for language teachers. In D. J. Young (Ed.), Affect in foreign language and second language learning: A practical guide to creating a low anxiety classroom atmosphere (pp. 24-45). Boston, MA: McGraw-Hill College.

MacIntyre, P. D. (2002). Motivation, anxiety and emotion in second language acquisition. In P. Robinson (Ed.), Individual differences and instructed language learning (pp. 45-68). Amsterdam: John Benjamins.

MacIntyre, P. D., \& Charos, C. (1996). Personality, attitudes, and affect as predictors of second language communication. Journal of Language and Social Psychology, 15, 3-26.

MacIntyre, P. D., \& Gardner, R. C. (1989). Anxiety and second language learning: toward a theoretical clarification. Language Learning, 39(2), 251-275.

MacIntyre, P. D., \& Gardner, R. C. (1991a). Language anxiety: Its relationship to other anxieties and to processing in native and second languages. Language Learning, 41(4), 513-534.

MacIntyre, P. D., \& Gardner, R. C. (1991b). Methods and results in the study of anxiety and language learning: A review of literature. Language Learning, 41(1), 85-117.

MacIntyre, P. D., \& Gardner, R. C. (1994). The subtle effects of language anxiety on cognitive processing in the second language. Language Learning, 44(2), 283-305.

MacIntyre, P. D., Baker, S. C., Clément, R., \& Donovan, L. A. (2002). Sex and age effects on willingness to communicate, anxiety, perceived competence, and L2 motivation among junior high school French immersion students. Language Learning, 52(3), 537-564.

MacIntyre, P. D., Noels, K. A., \& Clément, R. (1997). Biases in self-ratings of second language proficiency: The role of language anxiety. Language Learning, 47(2), 265-287.

Markus, H. R., \& Kitayama, S. (1998) The cultural psychology of personality. Journal of Cross-Cultural Psychology, 29(1), 63-87.

Markus, H., \& Nurius, P. (1986). Possible selves. American Psychologist, 41, 954-969.

McClelland, N. (2000). Goal orientations in Japanese college students learning EFL. In S. Cornwell \& P. Robinson (Eds.), Individual Differences in Foreign Language Learning: Effects of Aptitude, Intelligence, and Motivation (pp. 99-115). Tokyo: Japanese Association for Language Teaching.

McNamara, T. (1997). Theorizing social identity: what do we mean by social identity? Competing frameworks, competing discourses. TESOL Quarterly, 31(3), 561-567.

Mills, N., Pajares, F., \& Herron, C. (2007). Self-efficacy of college intermediate French students: Relation to achievement and motivation. Language Learning, 57(3), 417-442.

Moskovsky, C., Alrabai, F., Paolini, S., \& Ratcheva, S. (2013). The effects of teachers' motivational strategies on learners' motivation: A controlled investigation of second language acquisition. Language Learning, 63(1), 34-62.

Munezane, Y. (2015). Enhancing willingness to communicate: Relative effects of visualization and goal-setting. Modern Language Journal, 99(1), 175-191.

Nelson, J. M., \& Manset-Williamson, G. (2006). The impact of explicit, self-regulatory reading comprehension strategy instruction on the reading-specific self-efficacy, attributions, and affect of students with reading disabilities. Learning Disability Quarterly, 29(3), 213-230.

Noels, K. A. (2003). Learning Spanish as a second language: learners' orientations and perceptions of their teachers' communication style. In Z. Dörnyei (Ed.), Attitudes, Orientations, and Motivations in Language Learning (pp. 97-136). Oxford: Blackwell.

Norton, B. (1995). Social identity, investment, and language learning. TESOL Quarterly, 29(1), 9-31.

Oxford, R. L., \& Shearin, J. (1994). Language learning motivation: Expanding the theoretical framework. Modern Language Journal, 78(1), 12-28. 
Pajares, F. (1996). Self-efficacy beliefs in academic setting. Review of Educational Research, 66(4), 543-578.

Papi, M. (2010). The L2 Motivational Self System, L2 anxiety, and motivated behavior: A structural equation modeling approach. System, 38(3), 467-479.

Pérez-Paredes, P. F., \& Martinez-Sanchez, F. (2001). A Spanish version of the Foreign Language Classroom Anxiety Scale: Revisiting Aida's factor analysis. RESLA, 14, 337-352.

Ryan, S. (2009). Self and identity in L2 motivation in Japan: the ideal L2 self and Japanese learners of English. In Z. Dörnyei, \& E. Ushioda (Eds.), Motivation, Language Identity and the L2 Self (pp. 120-143). Bristol: Multilingual Matters, Clevedon.

Saito, Y., \& Samimy, K. (1996). Foreign language anxiety and language performance: a study of learner anxiety in beginning, intermediate, and advanced-level college students of Japanese. Foreign Languages Annals, 29, 239-251.

Schumacker, R. Lomax, R. (2004). A Beginner's Guide to Structural Equation Modeling (2nd Ed). Mahwah, NJ: Lawrence Erlbaum.

Scovel, T. (1978). The effect of affect on foreign language learning: a review of the anxiety literature. Language Learning, 28(1), 129-142.

Sparks, R. L., \& Patton, J. (2013). Relationships of L1 skills and L2 aptitude to L2 anxiety on the foreign language classroom anxiety scale. Language Learning, 63(4), 870-895.

Spielberger, C. D. (1983). Manual for the State-trait Anxiety Inventory. Palo Alto, CA: Consulting Psychologists Press.

Spielberger, C. D., Anton, W. D., \& Bedell, J. (1976). The nature and treatment of test anxiety. In M. Zuckerman, \& C. D. Spielberger (Eds.), Emotions and anxiety: New concepts, methods, and applications (pp. 317-344). Hillsdale, NJ: Erlbaum.

Taguchi, T., Magid, M., \& Papi, M. (2009). The L2 motivational self system amongst Chinese, Japanese, and Iranian learners of English: a comparative study. In Z. Dörnyei, \& E. Ushioda (Eds.), Motivation, Language Identity and the L2 Self (pp. 66-97). Bristol: Multilingual Matters, Clevedon.

Tóth, Z. (2008). A foreign language anxiety scale for Hungarian learners of English. WoPaLP, 2, 55-78.

Ueki, M., \& Takeuchi, O. (2012). Validating the L2 Motivational Self System in a Japanese EFL context: The interplay of L2 motivation, L2 anxiety, and the perceived amount of information. Language Education \& Technology, 49, 1-22.

Ueki, M., \& Takeuchi, O. (2013). Forming a clearer image of the ideal L2 self: The L2 Motivational Self System and learner autonomy in Japanese EFL context. Innovation in Language Learning and Teaching, 7(3), $238-252$

Ushioda, E. (2001). Language learning at university: exploring the role of motivational thinking. In Z. Dörnyei, \& R. Schmidt (Eds.), Motivation and Second Language Acquisition (pp. 91-124). Honolulu, HI: University of Hawaii Press.

Yashima, T. (2009). International posture and the ideal L2 self in the Japanese EFL context. In Z. Dörnyei, \& E. Ushioda (Eds.), Motivation, Language Identity and the L2 Self (pp. 144-163). Bristol: Multilingual Matters, Clevedon.

Young, D. J. (1991). Creating a low-anxiety classrooms environment: what does the anxiety research suggest? Modern Language Journal, 75(4), 426-439.

\section{Copyrights}

Copyright for this article is retained by the author(s), with first publication rights granted to the journal.

This is an open-access article distributed under the terms and conditions of the Creative Commons Attribution license (http://creativecommons.org/licenses/by/4.0/). 